\title{
Students' Attitudes and Perceptions towards the Effectiveness of Field Trips Strategyin Universitas Islam Riau, Pekanbaru
}

\author{
Rugaiyah \\ Universitas Islam Riau \\ email: ruqaiyah@edu.uir.ac.id
}

\begin{abstract}
This study aimed at exploring students' attitudes and perceptions about the effectiveness of field trips strategy. The participants of this study were 40 English students of Universitas Islam Riau, Pekanbaru, Indonesia. Both qualitative and quantitative methods were applied. This study employed an exploratory mixed-method design. The questionnaire consisted of three parts and 25 items which aimed at getting information about affective learning, the qualities among students and the contribution of a field trip on Society and Individuals. A five-point Likert-scale ranging from " strongly agree' to "strongly disagree" was asked to respondents to be selected. While a semi-structured interviewed was used together comprehensive information about the advantages of field trips in their study. The results of this study shown that field trips contribute to students' learning experience positively, besides it can solve many problems in the classroom and enhance the ability of students to think critically and creatively.
\end{abstract}

Keywords: Field Trip, Strategy, writing, descriptive text, students.

\begin{abstract}
Abstrak
Penelitian ini bertujuan mengeksplorasi sikap dan persepsi siswa tentang strategi kunjungan lapangan. Partisipan penelitian ini adalah 40 mahasiswa Bahasa Inggris Universitas Islam Riau, Pekanbaru, Indonesia. Metode kualitatif dan kuantitatif diterapkan. Penelitian ini menggunakan desain metode campuran eksplorasi. Kuesioner terdiri dari tiga bagian dan 25 item yang bertujuan untuk mendapatkan informasi tentang pembelajaran afektif, kualitas di antara siswa dan kontribusi dari kunjungan lapangan pada Masyarakat dan Individu. Lima poin skala Likert mulai dari "sangat setuju" hingga "sangat tidak setuju" diminta kepada responden untuk dipilih. Sementara wawancara semi-terstruktur digunakan bersama-sama informasi yang komprehensif tentang keuntungan kunjungan lapangan dalam studi mereka. Hasil penelitian ini menunjukkan bahwa kunjungan lapangan berkontribusi pada pengalaman belajar siswa secara positif, selain itu dapat memecahkan banyak masalah di kelas dan meningkatkan kemampuan siswa untuk berpikir kritis dan kreatif.
\end{abstract}

Kata Kunci: Field Trip, Strategi, penulisan, teks deskriptif, siswa. 


\section{INTRODUCTION}

Education plays an important role in human life which will affect human development throughout aspects of personality and life. It improves the value and excellence of one's life as well. Therefore, Education makes us more independent and aware of what is going on in the world today, along with the awareness of opportunities and rights. It also offers a greater understanding of one's capability and potential as well. Further, education motivates self-assurance and provides us with the things we need.

Education can be in the form of a formal and informal situation. It can take place anywhere, the classroom or outside of the classroom. However, learning outside the classroom is very important. Learning and teaching methods outside the classroom are very powerful in educating students, encouraging them to master various learning and to improve their performance compared to other classes with a learning system in the classroom. Students are also easier to understand lessons than learning in class. Outdoor learning does not only emphasizes the understanding of the lessons but also pays attention to students' ability in practicing it directly. Outside class education aims to enable students to adopt the natural environment and to know the important skills and experiences in their surroundings. According to Asmawati, et al (2008: 4.4) "outdoor play is very fun and important for children's growth and development".

Generally, in our country, Indonesia the schools or Institutions still keep the classical method, which is teaching in class. This is probably because they do not understand the notion of teaching outside the classroom and do not understand the importance of teaching outside the classroom. Therefore, classical teaching methods have always been the main reference in teaching.
Husamah (2013; 22) said: "Outdoor learning is also known as various other terms such as outdoor activities, outdoor study, field learning or learning outside the classroom and field trip". Therefore, this study adopted the term field trip which emphasizes students' perception and the advantages of educational field trips on students' learning. Educational Field trips have great potential positively in affecting students' learning (Farmer, Knapp and Benton, 2007) and students' attitudes towards their education (Hannon and Randolph, 1999; Michie, 1998). However, (Braund and Reiss, 2006) claimed that field trips provide real-world settings in which students are encouraged to challenge and apply knowledge learned in the classroom. As a result, most students enjoy a less formal setting in which the learning takes place, students also feel more excited about their school subjects (Michie, 1998; Storsdieck, 2001). Through field trip itself tends to be a short-term outing, the effects of this trip on students may continue for many months to years after the field trip (Farmer Knapp and Benton, 2007; Mackenzie and White, 1982).

The Field Trip is taken in a large group and students are included from different social backgrounds, educational field trip provides an opportunity for social training of the students. Hence, Jamilu and Salihu (2012) claimed that in a more relaxed environment, students have a chance to know and interact with each other. It is a great way to communicate difficult information. Most of the concepts and phenomena may be easily clarified, understood and assimilated and with the help of this through an educational field trip. Besides, it also can save a good deal of energy and time both of the teachers and students. A Field Trip can give a wonderful way to extend a learning experience in such a way that the students not only understand the concept but also understand how it connects to their world. On the whole, a Field Trip is also vital for 
students to have a chance to view and explore historical places and different social institutions.

Subsequently, students tend to learn the subject materials better if students have an interest (Haw-Jan "John" Wu (2009). Similarly, Tal and Morag (2009) described that field trips designed for educational purposes as student experiences outside of the classroom at interactive locations. Nabors, Edwards, and Murray (2009) asserted that the field trip is a type of experiential learning that gets children away from the traditional classroom setting and into a new mode of learning. Ajibade and Bamidele (2006) share the same view with the mentioned authors that field trip is the act of taking pupils out of the classroom into the community for the purpose of learning

Field trips can facilitate the construction of abstract concepts by providing the setting for long term memorized episodes. It means that field trips help students to connect their own with the experience concept. Futhermore, Meredith et al. (1997) and Behrendt Marc and Franklin (2014) also pointed out that students will get positive behavior about the material being discussed through direct participation during a field experience. Dole and Sinatra, (1998) The more authentic the mental exploration of the stimuli (e.g., testing, questioning, observing and making mental notes, selfexplaining, and critiquing of one's previous understanding, the more previously constructed schemas are retrieved and the more complex they become. Scarce (1997) posited that both personal experiences and lived social events that become - ways of knowing because field trips offer enriching experiences central to successful learning. According to Wright, (2000), Orion 1993, Noel 2007) students become excited and motivated to learn, spurring on new experiential activities since experiential learning activities allow students to participate in activities that help link theory and practice. It can be defined that field trips facilitate students to extend their learning experience. Otherwise, it does not only understand the concept but also understand how it connects to their word.

However, students still need someone to help them to link what they have explored during the trip and classroom concepts and discuss it with the whole class. However, to connect the concepts to students, experiences are through the social network. For this circumstance, the teacher was peering the students on how to complete the task and discussing their own experiences. Rennie (2007) observed that quite often the students who stepped out as peer instructors have been students who performed poorly in class. The outcome of an experience depends on a person's interests, motivation, life circumstances at that time, needs, and prior experiences and knowledge.

\section{METHOD}

The participants of this study were 40 English students of Universitas Islam Riau, Pekanbaru, Indonesia. This research aimed at exploring students' perception of field trip strategy. Both qualitative and quantitative methods were applied. This study employed an exploratory mixedmethod design.

Data collection technique (method) involved questionnaire and a semistructured interview. The purpose of the questionnaire was together information about the students' perception of the field trip strategy after the trips. The questionnaire was adapted from Shakil (2011) and the items which were only related to the current study included. The questionnaire consisted of three parts. The first part aimed to get the information about affective learning, these parts consisted of 10 items. The second part included 9 items which aimed at looking for information related to the qualities of among students. the last part was to find out the contribution of a field trip on Society and Individuals, this part 
employed 6 items. A five-point Likertscale ranging from " strongly agree' to "strongly disagree" was asked to respondents to be selected. While a semistructured interviewed was used together comprehensive information about the advantages of field trips in students learning.

In analyzing the data of the current study both quantitative and qualitative were involved. The quantitative data were analyzed into two phases; the first, the data of the questionnaire were analyzed using Statistical Packed for the Social Science SPSS in order to find out the frequencies and percentages. Then, Multivariate Analysis Test (Holtelling' Trace) was adopted to know the effect of $\mathrm{X}$ variable to the three variable of $\mathrm{Y}$ as seen in table 4 . Afterward, the test the Between-Subject Effect was used to obtain the effect of the field trip to each of the $\mathrm{Y}$ variables in table 5 .

While the qualitative data mutually supporting information that added both richness and depth to the emergent findings of the questionnaire The followup interview was held a week later in order together information about qualitative data. It was conducted with four of the participants in the questionnaire survey who volunteered to have the interview. The questions were given to the participants about the issues surround field trips.

\section{FINDING AND DISCUSSION}

\subsection{Field Trip is Helpful for Affective Learning}

The majority of students (92\%) think that field trips can give them the opportunity to relate their own experiences to the topics covered in the course. The responses of the respondents above were in line with several researcher's findings. Oreon (1993) found that field trips can facilitate the construction of abstract concepts by providing the setting for long term memorized episodes. It means that field trips contribute to students' learning experience and help them to relate the concept of what they have learned in the classroom. The students also deemed that Field trips also can help them to explore their learning experience (86\%). Besides, $(84.5 \%)$ agreed that field trips provide self-experience and observation in increasing their knowledge. Likewise, $(83.5 \%)$ believe that Field Trips contribute to their learning experience positively, besides, it also can help them to solve many problems in the classroom and enhances their ability to think critically and creatively. On the other hand, there were $(73 \%)$ of them consider that Field Trips give them an opportunity to adopt the various strategy of learning.

In regards to the students' perception of field trips in terms of affective learning. It appears that most of the students are satisfied with the trip. Between $70 \%$ 93.2\% believe that Field Trip gives them an opportunity to relate their own experiences to the topics covered in the course, provide self-experience \& observation to increase knowledge and help them to explore their learning experience. This finding is consistent with Nabors et al., (2009) claim that students on field trips sharpen their skills of observation and perception by utilizing all their senses. It means that when students have an interest, automatically students are eager to learn the subject materials better. Therefore, it is believed that field trips generate more interest and help students to bring more real-life experiences to the classroom. Hence, (Pedretti, 1997) suggests Field Trips become very important when they enhance school children's science learning by giving them authentic experiences, direct contact with real objects, and stimulating their curiosity and interest in the topic school, for (see, e.g., Falk, Koran, \& Dierking, 1986; Meredith, Fortner, \& Mullins, 1997). In addition, Oreon (1993) also pointed out that by providing students the setting of 
long term memorized episodes they can get the construction of abstract concepts.

Considering the above-studies, it seems that field trips can give students the opportunity to relate their own experiences to the topics covered in the course. Based on the resulting interview also indicated that students can connect the topic what they have leaned on the classroom to their experiences. Therefore, teachers need to connect the classroom curriculum to general learning experiences and provide exposure to new experiences in order to meet the student's needs. It means that students tend to learn the subject materials better when they have an interest.

However, someone who is able to understand the learning process and apply their knowledge gained from learning in real life, then he will be able to explain everything from his environment. Learning refers to behavioral changes that occur as a result of interactions between individuals and their environment. learning is a process by which an organism changes its behavior as a result of experience. It is connected to the result of students' interview that "they feel satisfied during the trip and they can see and observe the object which they couldn't in the classroom. They feel confident because they have many things to be discussed with others." This finding takes into account the idea proposed by (Aggarwal, 2008) who assessed that while students are on the trips they are able to show their abilities which are usually kept hidden in their classroom. Therefore, when students are in the classroom, they feel restricted by the rules and the duration of time in doing their assessments is limited. Otherwise, when learning in the field students feel free to learn the material while connecting their ideas to the subject have been studied before.

\subsection{Field Trip is Benefit to Promote the Required Qualities among Students}

Based on students' ideas about the benefits of field trips to promote the required qualities among students. Overall, the highest percentage of agreement goes to the terms Field Trips encourage them to increase self-confidence $(91.5 \%)$, it seems that students are free to gain information and explore their ideas by observing the object directly. However, based the above table shows that $(86.4 \%)$ students believe that field trip not only enabling them to develop leadership qualities but also makes them confident and allows them to comment and discuss ideas with their group more efficiently in sharing the idea to others in discussion. However, $(87 \%)$ of them believe that Field Trips help them to develop leadership qualities and allow them to explore their ideas in a classroom discussion. While it was only (79.25\%) of the respondents claim that Field Trips help them to promote a sense of discipline.

The idea of Field Trips promoting the qualities among students indicated that most of the students supported that the field Trips help them to increase selfconfidence, develop leadership qualities, sharpen the discussion/ interaction skills, comment and discuss ideas with the groups more efficiently and make them confidence in sharing the idea to others in discussion. This is in line with what Shakil and Hafeez (2011) pointed out that Educational Field Trips are very important because they are a way to bring the students closer together. In addition, it also helps them to develop the ability of obligation and leadership qualities in students. therefore, It's reasonable to assume that Field Trips help students achieve the learning outcomes set forth by the faculty.

Furthermore, the teacher takes an important part after the Field Trip. The teacher should reinforce the students' experiences through discussion, activities, reading, a television show or movie (Falk \& Dierking, 2000; Kisiel, 2006a; Orion \& Hofstein, 1994; Pace \& Tesi, 2004; Tal \& Steiner, 2006). The teacher helps students to solidify their new ideas and observations which have not yet made 
connections. After the trips students have new experiences concerning the objects they found, therefore the teacher should encourage them to explore their experiences through discussion by giving some questions related to the trips to them. As Kisiel, 2006a advocated that many connections concerning a subject will accommodate new knowledge faster and with greater clarity to a student reflection will help build those connections, as well. However, reinforce the successful connections already made on the trip. In this case, teachers have to develop potential connections through the reflection in order students can generate greater understanding After Field Trip Students have to discuss their observations and experiences, create presentations to share with their classmates. Further, Rennie \& Mc Cafferty, 1995 suggest that during the remainder of the school year, the teacher should connect new classroom concepts to the students' field trip experiences. However, to maximize student interest and learning, teachers must recognize the importance of post the field trip reflection and debriefing. This finding supported by Behrendt Marc and Franklin (2014) that students who directly participate during a field experience generate a more positive attitude about the subject

\subsection{Field Trip is Benefit for Society and Individual}

A large number of respondents (94\%) reveals that Field Trips are relevant to their study. Field Trips encourage students to participate effectively during the trip $(88 \%)$. Further, $(87.5 \%)$ of the respondents believe that Field Trips help them to know the importance of historical places and cultural heritage this point related to Eric Powell who describes that Field Trips are vital for seeing and understanding things. They provide an opportunity for the students to visiting a new place, meeting new people and Field Trips help them appreciate the relevance and importance of what they have learned in the classroom $(85 \%)$. Then $(84 \%)$ of the respondents fostering better performance in studies. Likewise, $(74.5 \%)$ of the respondents reported that Field Trips allow them to meet the need for higher education.

Based on the result of the interview given to volunteers that most of them enjoy the trip, and they are having fun in learning the material. However, they become satisfied and free to discuss their ideas with others. Every student comes to the classroom with different world experiences. However, students who have been exposed to many different things do better in school because it helps them to improve their skills and they feel confident in the discussion of student self-reported learning outcomes of field trips. It can be indicated most of the students were involved in the discussion and they are eager to explore their ideas related to their experience during the trips. Behrendt Marc and Franklin (2014) pointed out that field trip helps students to generate a more positive attitude about the subject if they directly participate during a field experience. Therefore, In order to be successful readers, students need to relate what they read to what they've experienced. To think broadly students need to have a variety of experiences. Moreover, in relation to this finding Shakil and Hafeez (2011) again asserted that Educational Field Trips provide an opportunity for social training of the students because Field Trips are taken in large group and students are included from different social backgrounds, it gives students a chance to get to know each other and interact in a more relaxed environment.

Moreover, Field Trips increase students' empathy towards others and the environment, help students understand the culture and history of their nation. It is believable that historical empathy is the ability to understand and appreciate what life was like for people who lived in a different time and place. This is a central 
purpose of teaching history, as it provides students with a clearer perspective about their own time and place. Therefore, social studies enhance student's critical thinking, tolerance, and historical empathy. In addition, When students take a Field Trip to a museum, park, gardens or local fire or police departments, they begin to understand, in a very concrete way, the value of these important community resources. Field Trips focusing on a "beach-sweep," or "street-sweep," allow students to participate in activities in which they become community advocates. Field trips provide living laboratories where students acquire knowledge outside the realm of the regular classroom.

\subsubsection{Multivariate Analysis Hotelling's Trace}

The result of the multivariate analysis can describe or show effect variable of the field trip (X) on a variable of Helpful in Effective Learning (Y1), variable of Promote the Required Qualities among Students (Y2), and variable of Beneficial for Society and Individuals (Y3). The result can be seen in the appendix.

Value of Variable $\mathrm{X}$ about 0.00 $(0.00<0.05)$. From the result of multivariate Tests, analysis can be concluded that variable of field trip effects significantly on a variable of Helpful in Effective Learning, variable of Promote the Required Qualities among Students, and variable of Beneficial for Society and Individuals. In other words, a field trip can increase the variable of helpful in effective learning, can increase the variable of promoting the required qualities among students, and can increase the variable of Beneficial for Society and Individuals.

\subsubsection{Test of Between-Subject Effect}

Test of Between-Subject Effect describes the effect variable of the field trip on the variable of Helpful in Effective Learning, variable of Promote the Required Qualities among Students, and variable of Beneficial for Society and Individuals. The result describes small or large effect variables of the field trip on the variable of Helpful in Effective Learning, variable of Promote the Required Qualities among Students, and variable of Beneficial for Society and Individuals. The result of the analysis can be seen in the appendix.

Based on Table of Test Of BetweenSubject Effect has obtained effect variable of the field trip on each of $\mathrm{Y}$ variable (variable of Helpful in Effective Learning (Y1), variable of Promote the Required Qualities among Students (Y2), and variable of Beneficial for Society and Individuals(Y3)). Variable of field trip effects significantly on the variable of Helpful in Effective Learning about 71.9\% $(\mathrm{R}$ Squared $=0.719 \times 100)$, variable of field trip effect significantly on the variable of Promote the Required Qualities among Students about 79.8\% (R Squared = $0.719 \times 100)$. Variable of field trip effect significantly on the variable of Beneficial for Society and Individuals71.3\% (R Squared $=0.719 \times 100)$. In line with this, Raiszadeh and Ettkin (1989) find that field trips provide a useful learning experience for students. Further,(Meiers, 2010; Anderson, 2003) also point out that the primary objective of field trips is to encourage students with an enjoyable opportunity for learning.

\section{Interview}

Student: 1 I feel satisfied during the trip because I can see and observe the object which I couldn't in the classroom. I feel confident because I have many things to be discussed with others.

Student 2: We are free to discuss our problem with other members of the group

Student 3: Field visit provides a valuable experience; I can witness history and tourist attractions in my country which I can usually only see through TV channels. 


\section{CONCLUSION}

In conclusion, the field trip is one of the best tools that can be used by teachers to provide every student with real-world experiences. Whether that's a trip to the local museum, park, a library, a community garden, a mosque, or a river, each experience that a student participates in contributes to their understanding of the world. On the whole. Students see the connections between what happened at school and in the 'real-world' when they are leaving the classroom. However, they begin to see that what they have learned within the classroom can help them solve the problems they see in the world around them that have a direct impact on who they become as people.

However, when learning in the field, Students are able to access tools and environments that can not be found in the classroom. Hence, students are able to see a river, an aquarium, museum, see dan touch historical facts in person and present on a public stage among hundreds of other things. Each experience solidifies learning and supports important academic concepts. with the selection of the right method, the teacher will be able to create conditions of learning that are meaningful and achieve maximum learning outcomes.

During the field trip. Rennie \& McClafferty, 1995 recommended that "while on a trip, it is the teacher's responsibility to help students feel comfortable in the new environment by interpreting the venue's program leader's commentary to any unfocused or confused students." It means that during the field trip, students get real-world experience of learning in an authentic, informal, and natural setting. However, students may get the opportunity to relate their own experiences to the topics covered in the course. This finding also supported by Pasquier \& Narguizian, 2006 claims that "students can make connections to the field trip experience using each of their prior knowledge, gained both from the classroom and from their personal out-ofschool experiences."

During the trip, the teacher grouping students into small groups, in which students will focus on their works. Therefore, they can interact more frequently in discussing the concepts and enhance them to get more connections between the concepts and the experience, however, students are hoped to be a better observer.

According to Wulandari (2013: 12) "outdoor learning" is an activity outside the classroom making learning outside the classroom interesting and fun, and more integrated with nature ", means that children have the opportunity to observe, obtain information or study everything directly. Providing learning experiences that are not found in the classroom and also giving an opportunity.

Furthermore, the teacher takes an important part after the field trip. The teacher should reinforce the students' experiences through the classroom discussion, by showing video activities, reading, a television show or movie (Orion \& Hofstein, 1994; Falk \& Dierking, 2000; Pace \& Tesi, 2004; Kisiel, 2006a; Tal \& Steiner, 2006). The teacher motivates the students to explore their ideas by observing the new place/object which has not yet made a connection. Moreover, students are easy to build up the connections which are already made on the trip. In addition, students also can generate greater understanding (Kisiel, 2006a).

After the trip, the teacher was grouping the students and asked them to create the presentation to report the result of their observation during the trip (Rennie \& McClafferty, 1995). In addition, Kisiel, 2006a stated that "To maximize student interest and learning, teachers must recognize the importance of post-field trip reflection and debriefing many connections concerning a subject will accommodate new knowledge faster and with greater clarity to a student." After the trip, based on the result of an interview 
given to volunteers that most of them enjoy the trip, they become satisfied and they are free to discuss their ideas to each other. After the trip students have new experiences concerning the object they found, therefore the teacher should encourage them to explore their experiences through discussion by giving some questions.

\section{REFERENCES}

Aggarwal, J.C. (2008). "Essentials of educational technology teachinglearning. Innovations in education", Vikas publishing house Pvt Ltd.

Behrendt, M. \& Franklin, T., (2014). A Review of Research on School Field Trips and Their Value in Education. International Journal of Environmental \& Science Education 9, 235-245.

Braund, M. and Reiss, M. (2006). Towards a more authentic science curriculum: The contribution of out-of-school learning. International Journal of Science Education, 28 (12).

Dole, J. and Sinatra, G. (1998). Reconceptualizing change in the cognitive construction of knowledge. Educational Psychologist, 33: 109-128.

Farmer, J., Knapp, D., \& Benton, G. M. (2007). An elementary school environmental education field trip: Long-term effects on ecological and environmental knowledge

and attitude development. The Journal of Environmental Education, 38(3).

Haw-Jan "John" Wu (2009). Using field trips to enhance student learning in operations management: Literature Review and Field Observations. California State University San Bernardino, CA. California Journal of Operations Management (C) 2009 CSU-POM ).

Jamilu, Ja'far and Salihu (2012) 'Effects of Educational Field Trips on Academic Performance of Junior Secondary School Social Studies Students in Kaduna State Nigeria
Kisiel, J. (2003). Teachers, museums, and worksheets: A closer look at learning experience. Journal of Science Teacher Education, 14, 3-21.

Lisowski, M. and Disinger, J.F. (1991).The effect of field-based instruction on student understanding of ecological concepts. Journal of Environmental Education, 23(11).

Michie M. (1998). Factors influencing secondary school teachers to organize and conduct field trips. Australian Science Teachers Journal, 44(4).

Nabors, M.L., Edwards, L.C., \& Murray, R. K., (2009). Making the case for field-trips: What research tells us and what site coordinators have to say. Education 129(4), 661-667.

National Research Council (2009). Learning science in informal environments: People,

places, and pursuits. Washington, DC: The National Academies Press.

Noel, A., "Elements of a Winning Field Trip," Kappa Delta Pi Record, Vol. 44(1), 2007,

42-44.

Oloyede, E. O., Ajibade, Y. A. \& Bamidele, E. F., (2006). Choice and effective use of teaching methods. In Ehindero, O J. Dibu-override O.O.and Ajibade, Y. A. Curriculum, and the teaching process. Ghana, Dama Educational Services

Ltd.

Orion, N., "A Model for the Development and Implementation of Field Trips as an Integral Part of the Science Curriculum," School Science and Mathematics, Vol. 93(6), 1993,325331.

Orion, N., \& Hofstein, A. (1994). Factors that influence learning during a scientific field trip in a natural environment. Journal of Research in Science Teaching, 31, 1097-1119.

Pace, S., Tesi, R. (2004). Adult's perception of field trips taken within grades K-12: Eight case studies in the 
New York metropolitan area. Education, 125(1), 30-40.

Price, S. \& Hein, G.E. (1991). More than a field trip: Science programs for elementary school groups at museums. International Journal of Science Education, 13(5),

Shakil, Faizi, Hafeez (2012) The Need and Importance of Field Trips at High Level in

Karachi, Pakistan. International Journal of Academic Research in Business

and Social Sciences. June (2011) Vol. 2, No.1.

Wison, T., Rick \& Brian, D., Till (2011) Effects of outdoor advertising: Does location

matter?https://onlinelibrary.wiley.com/ doi/abs/10.1002/mar.20418https://onlin elibrary.wiley.com/doi/abs/10.1002/mar .20418

Shakil, A.F, Faizi, W.N and Hafeez, S (2011), The Need and Importance of field trips at a Higher level in Karachi, Pakistan in International Journal of Academic Research in Business and Social sciences vol. 2, No.1

Tal, T., \& Morag, O. (2009). Reflective Practice as a Means for Preparing to Teach Outdoors in an Ecological Garden. Journal of Science Teacher Education, 20(3), 245-262.

Tal, T., \& Steiner, L. (2006). Patterns of teacher-museum staff relationships: School visits to the educational center of a science museum. Canadian Journal of Science, Mathematics and Technology Education, 6, 25-46.

(Q1 T1) Students find outdoor learning activities to be realistic, interesting and interactive (Hudak, 2003).

Hudak, P. (2003). Campus field exercises for introductory geoscience courses. Journal of Geography, 102(5), 220-225.

Rennie, L.J. (2007). Learning outside of school. In S.K. Abell and N.G. Lederman (eds.), Handbook of Research on Science Education. Mahwah, New Jersey: Erlbaum Using
Field Experiences," Journal of Instructional Psychology, Vol. 25(1), 1998,9-13.

DeWhite T.G. and Jacobson, S.K. (1994). Evaluating conservation education programs at a South American zoo. Journal of Environmental Education, 25(4), 1994 


\section{APPENDIX}

Field Trip is Helpful for Affective Learning

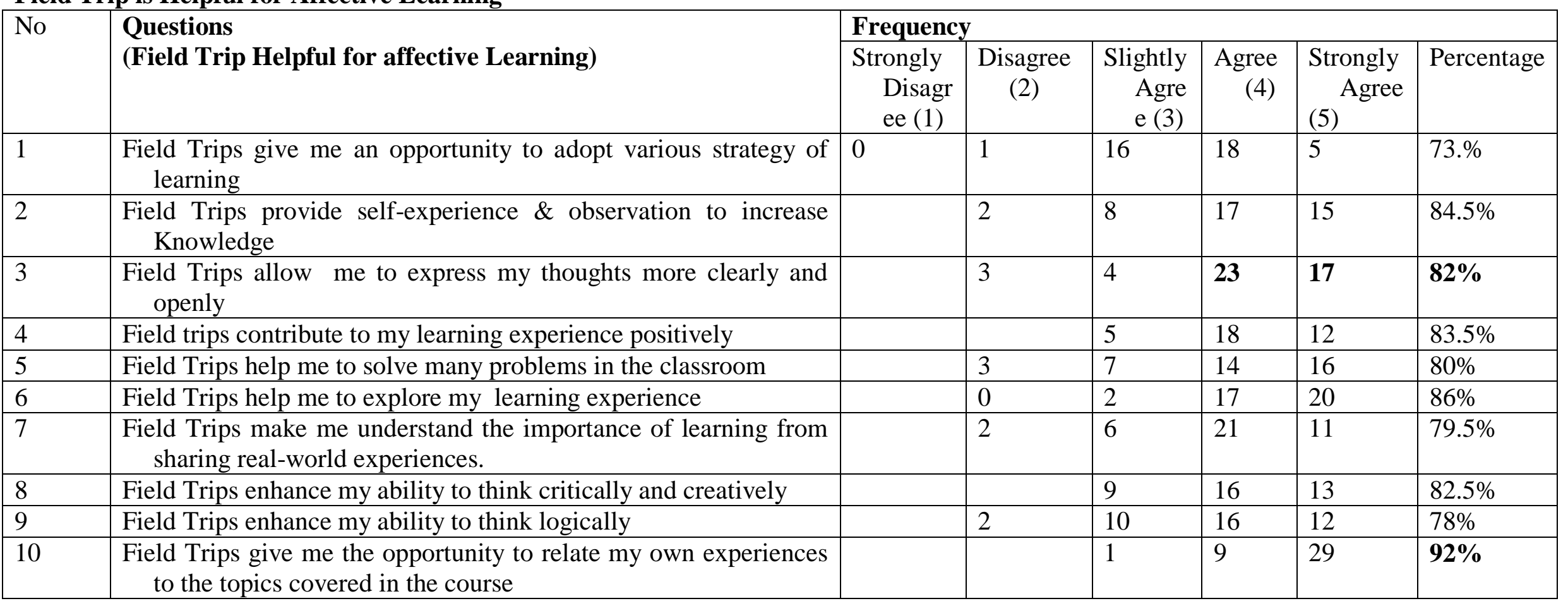


J-SHMIC : Journal of English for Academic

Vol 6, No 1, February 2019

$E-I S S N=2641-1446, P-I S S N=2356-2404$

Field Trips Promote Qualities among Students

\begin{tabular}{|c|c|c|c|c|c|c|c|}
\hline \multirow[t]{2}{*}{ No } & \multirow{2}{*}{$\begin{array}{l}\text { Questions } \\
\text { Field Trips Promote Qualities among Students }\end{array}$} & \multicolumn{6}{|c|}{ Frequency } \\
\hline & & $\begin{array}{c}\text { Strongly } \\
\text { Disag } \\
\text { ree } \\
(1)\end{array}$ & $\begin{array}{l}\text { Disagree } \\
\text { (2) }\end{array}$ & $\begin{array}{c}\text { Slightly } \\
\text { Agr } \\
\text { ee } \\
(3)\end{array}$ & $\begin{array}{r}\text { Agree } \\
(4)\end{array}$ & $\begin{array}{l}\text { Strongly } \\
\text { Agre } \\
\mathrm{e} \\
(5)\end{array}$ & Percentage \\
\hline 1 & $\begin{array}{l}\text { Field Trips encourage me to develop myself as a team } \\
\text { member }\end{array}$ & & 2 & 4 & 20 & 14 & $83 \%$ \\
\hline 2 & Field Trips enable me to increase self -confidence & & & 3 & 9 & 29 & $91.5 \%$ \\
\hline 3 & Field Trips sharpen my discussion/ interaction skills & & 1 & 2 & 25 & 12 & $83.5 \%$ \\
\hline 4 & Field Trips make me feel more involved with the class & & 0 & 5 & 22 & 13 & $84 \%$ \\
\hline 5 & Field Trips help me to promote a sense of discipline & & 2 & 5 & 23 & 10 & $79.25 \%$ \\
\hline 6 & Field Trips help me to develop leadership qualities & & 0 & 1 & 24 & 15 & $87 \%$ \\
\hline 7 & $\begin{array}{l}\text { Field Trips allow me to communicate more effectively } \\
\text { than traditional face-to-face meetings }\end{array}$ & & 1 & 2 & 26 & 11 & $84 \%$ \\
\hline 8 & $\begin{array}{l}\text { Field Trips allow me to comment and discuss ideas with } \\
\text { my group more efficiently as compared to traditional } \\
\text { classes. }\end{array}$ & & & 2 & 27 & 12 & $87 \%$ \\
\hline 9 & $\begin{array}{l}\text { Field Trips make me confidence in sharing an idea to } \\
\text { others in discussion }\end{array}$ & & 2 & 1 & 24 & 13 & $83.5 \%$ \\
\hline
\end{tabular}


J-SHMIC : Journal of English for Academic

Vol 6, No 1, February 2019

$E-I S S N=2641-1446, P-I S S N=2356-2404$

Field Trips is benefit for Society and Individuals

\begin{tabular}{|c|c|c|c|c|c|c|c|}
\hline \multirow[t]{2}{*}{ No } & \multirow{2}{*}{$\begin{array}{l}\text { Questions } \\
\text { Field Trips is a benefit for Society and Individuals }\end{array}$} & \multicolumn{6}{|c|}{ Frequency } \\
\hline & & \begin{tabular}{|c|} 
Strongly \\
Disag \\
ree \\
$(1)$
\end{tabular} & $\begin{array}{l}\text { Disagree } \\
\text { (2) }\end{array}$ & $\begin{array}{c}\text { Slightly } \\
\text { Agr } \\
\text { ee } \\
(3)\end{array}$ & $\begin{array}{l}\text { Agree } \\
\text { (4) }\end{array}$ & $\begin{array}{l}\text { Strongly } \\
\text { Agre } \\
\text { e } \\
(5)\end{array}$ & Percentage \\
\hline 1 & $\begin{array}{l}\text { Field trips help me to show better performance in } \\
\text { studies }\end{array}$ & & & 1 & 30 & 9 & $84 \%$ \\
\hline 2 & $\begin{array}{l}\text { Field Trips help me appreciate the relevance and } \\
\text { importance of what they have learned in the } \\
\text { classroom }\end{array}$ & & & 1 & 27 & 12 & $85 . \%$ \\
\hline 3 & $\begin{array}{l}\text { Field Trips allow me to meet the need the higher } \\
\text { education }\end{array}$ & & 6 & 9 & 15 & 10 & $74.5 \%$ \\
\hline 4 & This field trips are relevant to my study & & & 2 & 8 & 30 & $94 \%$ \\
\hline 5 & $\begin{array}{l}\text { Field trips help me to know the importance of } \\
\text { historical places and cultural heritage }\end{array}$ & & & & 25 & 15 & $87.5 \%$ \\
\hline 6 & $\begin{array}{l}\text { Field Trips encouraged me to participate effectively } \\
\text { during the trip }\end{array}$ & & & 1 & 22 & 17 & $88 \%$ \\
\hline
\end{tabular}




\section{J-SHMIC : Journal of English for Academic}

Vol 6, No 1, February 2019

$E-I S S N=2641-1446, P-I S S N=2356-2404$

Table 4. Multivariate Tests

\begin{tabular}{llllll}
\hline Effect & & Value & $\mathrm{F}$ & Error df & Sig. \\
\hline Intercept & Hotelling's Trace & .034 & $1.474^{\mathrm{a}}$ & 87.000 & .235 \\
$\mathrm{X}$ & Hotelling's Trace & 23.185 & $1.009 \mathrm{E} 3^{\mathrm{a}}$ & 87.000 & .000 \\
\hline
\end{tabular}

Table 5. Tests of Between-Subjects Effects

\begin{tabular}{|c|c|c|c|c|}
\hline & Dependent & & & \\
\hline Source & Variable & df & $\mathrm{F}$ & Sig. \\
\hline \multirow{3}{*}{$\begin{array}{r}\text { Corrected } \\
\text { Model }\end{array}$} & Y1 & 1 & 225.526 & .000 \\
\hline & Y2 & 1 & 348.540 & .000 \\
\hline & Y3 & 1 & 218.122 & .000 \\
\hline \multirow{3}{*}{ Intercept } & Y1 & 1 & 2.079 & .153 \\
\hline & Y2 & 1 & 2.885 & .093 \\
\hline & Y3 & 1 & .063 & .802 \\
\hline \multirow{3}{*}{$X$} & Y1 & 1 & 225.526 & .000 \\
\hline & Y2 & 1 & 348.540 & .000 \\
\hline & Y3 & 1 & 218.122 & .000 \\
\hline \multicolumn{5}{|c|}{ R Squared $=.719($ Adjusted R Squared $=.716)$} \\
\hline \multicolumn{5}{|c|}{ R Squared $=.798($ Adjusted R Squared $=.796)$} \\
\hline \multicolumn{5}{|c|}{ R Squared $=.713($ Adjusted R Squared $=.709)$} \\
\hline
\end{tabular}

